\title{
Figuring Out Fertilizer for the Home Lawn ${ }^{1}$
}

\section{L.E. Trenholm and J.B. Unruh²}

Applying the correct amount of fertilizer to your home lawn is critical for two reasons:

1.The health and vigor of your lawn depends upon applying the right amount of fertilizer, with too little or too much fertilizer causing problems for the growth, appearance, and health of your lawn.

2.Improper application of fertilizer can harm the environment. Over-application or misapplication of fertilizer can potentially result in leaching of chemicals through the soil into ground water supplies or run-off of chemicals into surface water. On the other hand, applying too little fertilizer may result in a lawn with minimal density of root and shoot systems, which will allow for leaching to occur more readily. Since this is an important environmental issue, we need to ensure that we handle fertilizers properly and apply the correct amounts when we fertilize.

Although there are a number of different types of fertilizer sold for home lawns, there are a few basics that apply to all of them:

- The three numbers on the bag represent the amounts of nitrogen, phosphorus, and potassium in the bag.
- Look for a fertilizer with low amounts of phosphorus for your lawn unless a soil test indicates the need for phosphorus.

- Fertilizers with larger amounts of slow-release nitrogen are less apt to leach if mis-applied.

- The potential for leaching or run-off is directly related to the amount of water, either from irrigation or rainfall, that is applied following fertilizing. Some irrigation is generally required to wash the fertilizer off the leaf blades, but too much can wash it past the root zone where it won't be taken up. Apply about 1/4 inch of water to properly irrigate fertilizer in.

- The label is the law! Always read and follow instructions.

- Fertilizer needs differ due to grass species, your location in the state, and your desired level of lawn care. Refer to fact sheets relating to your particular grass or go to http://turf.ufl.edu for more information on this.

- Professional lawn care services that are licensed are required to receive training to renew their licenses. These companies have a wider

1. This document is ENH962, one of a series of the Environmental Horticulture Department, Florida Cooperative Extension Service, Institute of Food and Agricultural Sciences, University of Florida. Original publication date September 9, 2003. Visit the EDIS Web Site at http://edis.ifas.ufl.edu.

2. L.E. Trenholm, Assistant Professor, Turfgrass Specialist, Department of Environmental Horticulture, Institute of Food and Agricultural Sciences, University of Florida, Gainesville, FL. 32611

J.Bryan Unruh, Associate Professor, Turfgrass Specialist, West Florida Research and Education Center, Institute of Food and Agricultural Sciences, Milton, FL. 32570

All chemicals should be used in accordance with directions on the manufacturer's label.

The Institute of Food and Agricultural Sciences (IFAS) is an Equal Employment Opportunity - Affirmative Action Employer authorized to provide research, educational information and other services only to individuals and institutions that function without regard to race, creed, color, religion, age, disability, sex, sexual orientation, marital status, national origin, political opinions or affiliations. For information on obtaining other extension publications, contact your county Cooperative Extension Service office. Florida Cooperative Extension Service / Institute of Food and Agricultural Sciences / University of Florida / Larry R. Arrington, Interim Dean 
variety of products, application methods, and greater expertise and therefore may apply fertilizer differently than recommended for homeowners.

To determine how to apply the correct amount of fertilizer, follow these simple steps.

1. Know the annual fertility needs for your grass species. See Table 1 for the range of recommended fertility rates in Florida or go to http://turf.ufl.edu for more information.

Table 1.

\begin{tabular}{|c|c|}
\hline Species/Location & $\begin{array}{c}\text { Interim N } \\
\text { Recommendations } \\
\left(\text { Ibs } 1000 \mathrm{ft}^{-2} \mathrm{yr}^{-1}\right)^{\star},{ }^{\star *}\end{array}$ \\
\hline Bahiagrass- North & $2-3$ \\
\hline Bahiagrass- Central & $2-4$ \\
\hline Bahiagrass-South & $2-4$ \\
\hline Bermudagrass- North & $3-5$ \\
\hline Bermudagrass- Central & $4-6$ \\
\hline Bermudagrass- South & $5-7$ \\
\hline Centipedegrass- North & $1-2$ \\
\hline Centipedegrass- Central & $2-3$ \\
\hline Centipedegrass- South & $2-3$ \\
\hline St. Augustinegrass- North & $2-4$ \\
\hline St. Augustinegrass- Central & $2-5$ \\
\hline St. Augustinegrass- South & 4-6 \\
\hline Zoysiagrass- North & $3-5$ \\
\hline Zoysiagrass- Central & $3-6$ \\
\hline Zoysiagrass- South & 4-6 \\
\hline \multicolumn{2}{|c|}{$\begin{array}{l}\text { *Homeowner preferences for lawn quality and } \\
\text { maintenance level will vary, therefore we recommend a } \\
\text { range of fertility rates for each grass and location. } \\
\text { Additionally, effects within a localized region (i.e., } \\
\text { micro-environmental influences such as shade, drought, } \\
\text { soil conditions, and irrigation) will necessitate that a } \\
\text { range of fertility rates be used. } \\
\text { **These recommendations assume that grass clippings } \\
\text { are recycled. }\end{array}$} \\
\hline
\end{tabular}

2. Know the square footage of your lawn. To determine this, walk off your property and calculate the total square footage of turfgrass. Do not include landscape plants in the area to be fertilized under a turfgrass regime. For this example, we will assume that your total area of grass covers approximately 1000 square feet.

3. Know your fertilizer analysis. Say you purchase a 50-pound bag of 15-2-15 fertilizer. The three numbers mean that $15 \%$ of the bag is nitrogen, $2 \%$ is phosphorus as $\mathrm{P}_{2} \mathrm{O}_{5}(0.86 \%$ phosphorus $)$, and $15 \%$ is potassium as $\mathrm{K}_{2} 0(12.5 \% \mathrm{~K})$. See Figure 1 for an example of a fertilizer label.

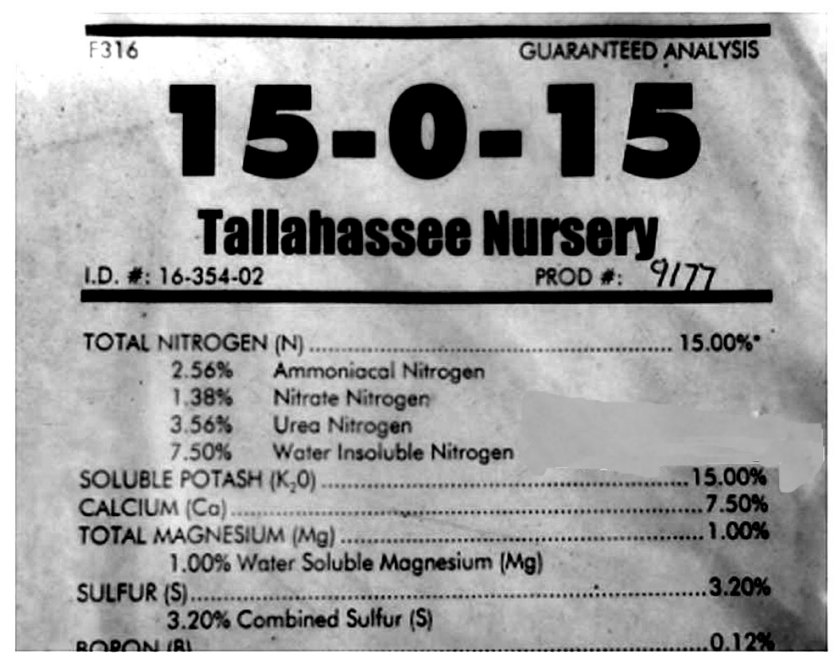

Figure 1. Fifty percent of the nitrogen listed on this fertilizer label is water insoluble, or slow-release.

4. Determine how much slow-release nitrogen is in the fertilizer product you are using. Look at how much nitrogen $(\mathrm{N})$ is slow-release in the fertilizer. In figure $1,50 \%$ of the nitrogen is water insoluble, or slow-release. Homeowners should look for high percentages of slow-release $\mathrm{N}$ to reduce the potential for any pollution of water resources resulting from the fertilization. If using a fertilizer with at least $30 \%$ slow-release $\mathrm{N}$ or more, you can apply up to 1 pound of nitrogen per 1,000 square feet with each application. If less than $30 \%$ is slow-release, only apply $1 / 2$ pound of nitrogen per 1,000 square feet with each application.

\section{How do I know how much fertilizer $1 / 2$ or 1} lb per 1,000 square feet is? Look at table 2 for this. If you know the square footage of your lawn, you can easily calculate how much fertilizer to apply from this table based on what percentage nitrogen is in your fertilizer. These figures are based on application of $1 / 2$ pound of fertilizer per 1,000 square feet. If you 
are applying a slow-release product, double these amounts to apply 1 pound per 1,000 square feet.

6. Setting your spreader. Spreader models differ and not all will have the same setting for a particular brand of fertilizer. The safest way to not over-apply fertilizer is to set the spreader on the smallest setting, put in your 6.5 cups of fertilizer (or whatever amount for the product and size of the area that you are covering) and go over the area in a north/south direction. When you have covered the area to which you are applying product, or when you have half of the fertilizer left in the hopper, turn around and cover in an east/west orientation until you run out of fertilizer. 
Table 2. Examples of proper application rates for specific fertilizer products: In the table below, values given represent the percentage of $\mathrm{N}$ (across top) in the fertilizer bag and the number of square feet of lawn area (left-hand side) that you have. Remember that $\mathrm{N}$ is the first of the three numbers on the fertilizer bag. The first value given is the weight of fertilizer to use for the given lawn area in pounds. The second number tells how many cups of fertilizer this equals.

\begin{tabular}{|c|c|c|c|c|c|c|c|}
\hline $\begin{array}{l}\text { Lawn } \\
\text { (square } \\
\text { feet) }\end{array}$ & $6 \% \mathrm{~N}^{*}$ & $10 \% \mathrm{~N}^{*}$ & $12 \% \mathrm{~N}^{*}$ & $15 \% \mathrm{~N}^{\star}$ & $16 \% \mathrm{~N}^{*}$ & $23 \% \mathrm{~N}^{*}$ & $27 \% N^{*}$ \\
\hline 1000 & $\begin{array}{l}8.4 \mathrm{lbs} . \\
17.4 \text { cups }\end{array}$ & $\begin{array}{l}5 \mathrm{lbs} . \\
9.5 \mathrm{cups}\end{array}$ & $\begin{array}{l}4.2 \mathrm{lbs} . \\
8.7 \text { cups }\end{array}$ & $\begin{array}{l}3.3 \mathrm{lbs} . \\
7.25 \text { cups }\end{array}$ & $\begin{array}{l}3.1 \mathrm{lbs} . \\
6.5 \text { cups }\end{array}$ & $\begin{array}{l}2.2 \mathrm{lbs} . \\
5.5 \mathrm{cups}\end{array}$ & $\begin{array}{l}1.9 \mathrm{lbs} . \\
4.75 \mathrm{cups}\end{array}$ \\
\hline 1100 & $\begin{array}{l}9.2 \text { lbs. } \\
19.2 \text { cups }\end{array}$ & $\begin{array}{l}5.5 \mathrm{lbs} . \\
10.5 \text { cups }\end{array}$ & $\begin{array}{l}4.6 \text { lbs. } \\
9.6 \text { cups }\end{array}$ & $\begin{array}{l}3.6 \text { lbs. } \\
8.0 \text { cups }\end{array}$ & $\begin{array}{l}3.4 \mathrm{lbs} . \\
7.25 \text { cups }\end{array}$ & $\begin{array}{l}2.4 \text { lbs. } \\
6.1 \mathrm{cups}\end{array}$ & $\begin{array}{l}2.1 \mathrm{lbs} . \\
5.25 \mathrm{cups}\end{array}$ \\
\hline 1200 & $\begin{array}{l}10.2 \text { lbs. } \\
20.8 \text { cups } \\
\end{array}$ & $\begin{array}{l}6 \mathrm{lbs} \\
11.5 \text { cups } \\
\end{array}$ & $\begin{array}{l}5.1 \mathrm{lbs} . \\
10.4 \text { cups } \\
\end{array}$ & $\begin{array}{l}4.0 \mathrm{lbs} . \\
8.7 \mathrm{cups} \\
\end{array}$ & $\begin{array}{l}3.7 \mathrm{lbs} . \\
7.75 \text { cups }\end{array}$ & $\begin{array}{l}2.6 \mathrm{lbs} . \\
6.6 \mathrm{cups} \\
\end{array}$ & $\begin{array}{l}2.3 \mathrm{lbs} . \\
5.75 \mathrm{cups} \\
\end{array}$ \\
\hline 1300 & $\begin{array}{l}11.0 \mathrm{lbs} . \\
22.6 \mathrm{cups}\end{array}$ & $\begin{array}{l}6.5 \mathrm{lbs} . \\
12.5 \text { cups }\end{array}$ & $\begin{array}{l}5.5 \mathrm{lbs} . \\
11.3 \mathrm{cups}\end{array}$ & $\begin{array}{l}4.3 \mathrm{lbs} . \\
9.4 \mathrm{cups}\end{array}$ & $\begin{array}{l}4 \mathrm{lbs} . \\
8.5 \text { cups }\end{array}$ & $\begin{array}{l}2.8 \mathrm{lbs} . \\
7.2 \mathrm{cups}\end{array}$ & $\begin{array}{l}2.5 \mathrm{lbs} . \\
6.25 \mathrm{cups}\end{array}$ \\
\hline 1400 & $\begin{array}{l}12.0 \mathrm{lbs} . \\
24.4 \text { cups }\end{array}$ & $\begin{array}{l}7.0 \mathrm{lbs} . \\
13.5 \mathrm{cups} \\
\end{array}$ & $\begin{array}{l}6.0 \mathrm{lbs} . \\
12.2 \text { cups } \\
\end{array}$ & $\begin{array}{l}4.6 \mathrm{lbs} . \\
10.2 \text { cups } \\
\end{array}$ & $\begin{array}{l}4.5 \mathrm{lbs} . \\
9 \text { cups }\end{array}$ & $\begin{array}{l}3.1 \mathrm{lbs} . \\
7.7 \mathrm{cups} \\
\end{array}$ & $\begin{array}{l}2.7 \mathrm{lbs} . \\
6.75 \mathrm{cups} \\
\end{array}$ \\
\hline 1500 & $\begin{array}{l}13.0 \text { lbs. } \\
26.2 \text { cups } \\
\end{array}$ & $\begin{array}{l}7.5 \mathrm{lbs} . \\
14.25 \text { cups } \\
\end{array}$ & $\begin{array}{l}6.5 \mathrm{lbs} . \\
13.1 \mathrm{cups} \\
\end{array}$ & $\begin{array}{l}4.9 \mathrm{lbs} . \\
10.9 \mathrm{cups}\end{array}$ & $\begin{array}{l}4.75 \text { lbs. } \\
9.75 \text { cups }\end{array}$ & $\begin{array}{l}3.3 \text { lbs. } \\
8.3 \text { cups } \\
\end{array}$ & $\begin{array}{l}2.9 \mathrm{lbs} . \\
7.25 \mathrm{cups} \\
\end{array}$ \\
\hline 2000 & $\begin{array}{l}16.8 \mathrm{lbs} . \\
34.8 \text { cups } \\
\end{array}$ & $\begin{array}{l}10 \text { lbs. } \\
19 \text { cups }\end{array}$ & $\begin{array}{l}8.4 \mathrm{lbs} . \\
17.4 \mathrm{cups}\end{array}$ & $\begin{array}{l}6.6 \mathrm{lbs} . \\
14.5 \mathrm{cups} \\
\end{array}$ & $\begin{array}{l}6.2 \text { lbs. } \\
13 \text { cups }\end{array}$ & $\begin{array}{l}4.4 \mathrm{lbs} . \\
11.0 \mathrm{cups}\end{array}$ & $\begin{array}{l}3.8 \text { lbs. } \\
9.5 \text { cups } \\
\end{array}$ \\
\hline 2500 & $\begin{array}{l}21.0 \mathrm{lbs} \\
43.6 \text { cups }\end{array}$ & $\begin{array}{l}12.5 \mathrm{lbs} . \\
23.75 \mathrm{cups}\end{array}$ & $\begin{array}{l}10.5 \mathrm{lbs} . \\
21.8 \text { cups }\end{array}$ & $\begin{array}{l}8.2 \text { lbs. } \\
18.2 \text { cups }\end{array}$ & $\begin{array}{l}7.8 \mathrm{lbs} . \\
16.25 \text { cups }\end{array}$ & $\begin{array}{l}5.5 \mathrm{lbs} . \\
13.8 \text { cups }\end{array}$ & $\begin{array}{l}4.8 \text { lbs. } \\
12 \text { cups }\end{array}$ \\
\hline 3000 & $\begin{array}{l}25.2 \text { lbs. } \\
52.2 \text { cups }\end{array}$ & $\begin{array}{l}15 \mathrm{lbs} . \\
28.5 \text { cups } \\
\end{array}$ & $\begin{array}{l}12.6 \text { lbs. } \\
26.1 \text { cups } \\
\end{array}$ & $\begin{array}{l}9.8 \mathrm{lbs} . \\
21.8 \mathrm{cups} \\
\end{array}$ & $\begin{array}{l}9.4 \mathrm{lbs} . \\
19.5 \mathrm{cups}\end{array}$ & $\begin{array}{l}6.6 \mathrm{lbs} . \\
16.6 \mathrm{cups} \\
\end{array}$ & $\begin{array}{l}5.8 \mathrm{lbs} . \\
14.5 \mathrm{cups} \\
\end{array}$ \\
\hline 3500 & $\begin{array}{l}29.4 \text { lbs. } \\
61 \text { cups }\end{array}$ & $\begin{array}{l}17.5 \mathrm{lbs} . \\
33.25 \mathrm{cups}\end{array}$ & $\begin{array}{l}14.7 \mathrm{lbs} . \\
30.5 \text { cups }\end{array}$ & $\begin{array}{l}11.5 \text { lbs. } \\
25.4 \text { cups }\end{array}$ & $\begin{array}{l}11 \mathrm{lbs} . \\
22.75 \text { cups }\end{array}$ & $\begin{array}{l}7.7 \mathrm{lbs} . \\
19.3 \text { cups }\end{array}$ & $\begin{array}{l}6.8 \text { lbs. } \\
17 \text { cups }\end{array}$ \\
\hline 4000 & $\begin{array}{l}33.6 \mathrm{lbs} . \\
69.6 \text { cups }\end{array}$ & $\begin{array}{l}20 \text { lbs. } \\
38 \text { cups }\end{array}$ & $\begin{array}{l}16.8 \mathrm{lbs} . \\
34.8 \text { cups }\end{array}$ & $\begin{array}{l}13.2 \text { lbs. } \\
29 \text { cups } \\
\end{array}$ & $\begin{array}{l}12.6 \text { lbs. } \\
26 \text { cups }\end{array}$ & $\begin{array}{l}8.8 \mathrm{lbs} . \\
22.0 \text { cups }\end{array}$ & $\begin{array}{l}7.8 \mathrm{lbs} . \\
19.5 \mathrm{cups} \\
\end{array}$ \\
\hline 4500 & $\begin{array}{l}37.8 \mathrm{lbs} . \\
78.4 \text { cups }\end{array}$ & $\begin{array}{l}22.5 \mathrm{lbs} . \\
42.75 \text { cups }\end{array}$ & $\begin{array}{l}18.9 \text { lbs. } \\
39.2 \text { cups }\end{array}$ & $\begin{array}{l}14.8 \mathrm{lbs} . \\
32.7 \text { cups }\end{array}$ & $\begin{array}{l}14.2 \mathrm{lbs} . \\
29.25 \text { cups }\end{array}$ & $\begin{array}{l}9.9 \mathrm{lbs} . \\
24.8 \text { cups }\end{array}$ & $\begin{array}{l}8.8 \mathrm{lbs} . \\
22 \text { cups }\end{array}$ \\
\hline 5000 & $\begin{array}{l}42 \text { lbs. } \\
87.2 \text { cups }\end{array}$ & $\begin{array}{l}25 \text { lbs. } \\
47.5 \text { cups }\end{array}$ & $\begin{array}{l}21 \mathrm{lbs} . \\
43.6 \text { cups }\end{array}$ & $\begin{array}{l}16.4 \text { lbs. } \\
36.4 \text { cups }\end{array}$ & $\begin{array}{l}15.8 \mathrm{lbs} . \\
32.5 \text { cups }\end{array}$ & $\begin{array}{l}11.0 \text { lbs. } \\
27.6 \text { cups }\end{array}$ & $\begin{array}{l}9.8 \mathrm{lbs} . \\
24.5 \text { cups }\end{array}$ \\
\hline \multicolumn{8}{|c|}{$\begin{array}{l}\text { * The percentage corresponds to the first of the three numbers found on the bag. For example, use } \\
\text { the } 15 \% \text { calculations when using a } 15-2-15 \text { product. These figures assume that you are applying } \\
\text { the recommended rate of } 1 / 2 \text { pound of nitrogen per } 1,000 \text { square feet. For more information on lawn } \\
\text { fertilization, please refer to the Residential Landscape section of http://turf.ufl.edu or consult your } \\
\text { local County Extension Service office for lawn fertilization fact sheets. }\end{array}$} \\
\hline
\end{tabular}

